\title{
FAKTOR-FAKTOR YANG MEMPENGARUHI PEMILIHAN PREMIS MAKANAN DALAM KALANGAN MELAYU MUSLIM BANDAR: SATU SOROTAN LITERATUR
}

\section{Factors that Influence Food Premise Selection Among Urban Malay Muslims: A Literature Review}

\author{
Hazwani Kamarudin* \\ Norhidayah Pauzi* \\ Saadan Man ${ }^{* * *}$ \\ Syed Mohd Jeffri Syed Jaafar ${ }^{* * * *}$
}

\begin{abstract}
Based on the State of the Global Islamic Economy Report 2018/19, Malaysia is a pioneer in establishing a world-leading Islamic economy. Much research has been conducted on the awareness, understanding,
\end{abstract}

* Master Candidate, Department of Fiqh and Usul, Academy of Islamic Studies, University of Malaya, 50603 Kuala Lumpur, Malaysia, hazwanikhaulah96@gmail.com

** Senior Lecturer, Department of Fiqh and Usul, Academy of Islamic Studies, University of Malaya, 50603 Kuala Lumpur, Malaysia,da_my85@um.edu.my

*** Associate Professor, Department of Fiqh and Usul, Academy of Islamic Studies, University of Malaya, 50603 Kuala Lumpur, Malaysia,saadan@um.edu.my

**** Senior Lecturer, Department of Fiqh and Usul, Academy of Islamic Studies, University of Malaya, 50603 Kuala Lumpur, Malaysia, syedjeffri89@um.edu.my 
behavior and choosing of halal foods among Muslims for several years. However, many issues regarding halal foods are still unresolved. It is viral in the social and electronics media about the misuse of the halal logo, cleanliness of the food premises, misunderstandings on halal food premises and 'viral' foods. As customers play a vital role in determining the development of the halal industry, this study identifies and analyzes several factors that influence the choice of food premises among urban Malay Muslims. Data collection is done by the method of documentation and which is then analyzed through inductive analysis. The findings show that many factors come into play when customers purchase food on the premises such as attitudes, subjective norms, perceived behavioral control, religiosity, the halal certificate and logo, demographic factors, culture, service quality at food premises and food attributes. Therefore, based on this library study, it is hoped that the selection of food premises among urban Malay Muslims would be continuously researched upon.

Keywords: food, halal, premise, customer

\section{PENDAHULUAN}

Industri halal merupakan antara industri yang pesat berkembang. Nilai dagangan dunia industri kini mencecah US\$2.3 trilion setahun dengan sektor makanan halal sebagai komponen teras yang bernilai US\$660 bilion. ${ }^{1}$ Prospek permintaan produk halal mendapat sambutan yang tinggi di peringkat global tanpa mengira bangsa dan agama. Permintaan ini menggambarkan bahawa produk halal mampu menarik minat pasaran global dan seterusnya meluaskan perniagaan eksport ke pasaran negara-negara bukan

\footnotetext{
"Pengguna Perlu Lebih Maklumat Dalam Isu Halal," laman sesawang mStar, dicapai pada 21 April 2019, http://www.mstar.com. my/lain-lain/rencana/2010/02/09/pengguna-perlu-lebih-maklumatdalam-isu- halal/\#ZdMYXDi2qfU0vw21.99.
} 
Islam dan juga negara-negara Islam yang lain. Selain itu, Bahagian Pengurusan Halal Jabatan Kemajuan Islam Malaysia (JAKIM) turut memainkan peranan utama dalam mengkaji, mengesah dan mengawal selia produk makanan dan barangan gunaan Islam supaya terjamin halal dan suci. Walau bagaimanapun, permohonan sijil halal adalah bersifat sukarela. ${ }^{2}$

Meskipun Malaysia merupakan peneraju industri halal, namun wujud permasalahan dalam pemilihan premis makanan antaranya sambutan pemegang pensijilan halal dalam kalangan bumiputera kurang berbanding bukan bumiputera. ${ }^{3}$ Malah, terdapat isu yang boleh mengelirukan pengguna Muslim seperti serve no pork ${ }^{4}$ dan isu penyalahgunaan logo halal. ${ }^{5}$ Selain itu, premis makanan antarabangsa pesat berkembang di bandar. Para pengguna Muslim turut tidak ketinggalan untuk mencuba citarasa baru. Hal ini telah mengubah tabiat pemakanan budaya tempatan masyarakat Melayu Muslim. ${ }^{6}$ Bahkan, peningkatan taraf hidup moden dan kesibukan dalam mencari pendapatan boleh menyebabkan pengguna Melayu Muslim bandar mudah terdedah dengan isu pemilihan

2 Nazura Ngah, Hazwan Faisal Mohamad dan Fahmy Azril Rosli, "Pensijilan Halal Malaysia Sukarela, Terbuka Semua", laman sesawang Berita Harian, dicapai pada 18 Oktober 2019, https:// www.bharian.com.my/berita/nasional/2017/07/305557/persijilanhalal-malaysia-sukarela-terbuka-semua.

3 Ahmad Faidhi Mohd Sidek, "Permasalahan Dalam Permohonan Sijil Halal dalam kalangan Usahawan Perusahaan Kecil dan Sederhana (PKS) di Malaysia" (tesis sarjana, Akademi Pengajian Islam, Universiti Malaya, 2017).

4 Nora Mahpar, Mohd Nasaruddin Parzi dan Nur Fatin Mohd Satar, "Restoran Pamer Tanda 'Tiada Babi' Cetus Persoalan," laman sesawang Berita Harian Online, dicapai pada 29 Ogos 2019, https:// www.bharian.com.my/node/123917.

5 Muhammad Basir Roslan dan Bernama, "Tangani Segera Isu Salah Guna Sijil Halal Sebelum Parah," laman sesawang MalaysiaKini, dicapai 9 Jun 2020, https://www.malaysiakini.com/news/463637.

6 Mohd Anuar Ramli dan Mohammad Aizat Jamaludin, "Budaya Makanan dan Pemakanan Halal dalam Kalangan Masyarakat Melayu menurut Perspektif Islam," dalam Penyelidikan tentang Makanan: PerspektifNabawi dan Saintifik, ed. Mohd Yakub@Zulkifli Mohd Yusoff, Khadher Ahmad dan Monika@ Munirah Abd Razzak (Kuala Lumpur: Jabatan Al-Quran dan Al-Hadith, 2016), 195-206. 
premis makanan. ${ }^{7}$ Oleh itu, berdasarkan beberapa isu yang telah dinyatakan, maka satu sorotan literatur berkaitan faktor-faktor yang mempengaruhi pemilihan premis makanan dalam kalangan pengguna Melayu Muslim bandar diperlukan bagi mendapatkan gambaran umum. Justeru, peningkatan pensijilan halal khususnya dalam industri makanan di Malaysia perlu kepada usaha bersepadu antara kerajaan, masyarakat dan pengusaha makanan. Begitu juga, pengguna mestilah membantu meningkatkan promosi pensijilan halal melalui pemilihan premis makanan yang mempunyai logo halal. Malah, mencari makanan halal merupakan suatu kewajipan kepada setiap individu Muslim.

\section{KONSEP PEMAKANAN HALĀLAN TAYYIBAN DALAM ISLAM}

Istilah halal berasal daripada perkataan Arab, iaitu halla, yahillu, hillan, halalan yang membawa maksud dibenarkan atau dibolehkan oleh hukum syarak. Halal juga ditakrifkan sebagai sesuatu yang diharuskan, yang terungkai padanya ikatan larangan dan diizinkan oleh syarak untuk melakukannya. Ia juga bermaksud sesuatu yang dibenarkan dalam undang-undang Islam yang termaktub dalam al-Quran, hadis, ijma' dan qiyas. ${ }^{8}$ Makanan pula merupakan keperluan asas bagi kehidupan manusia. Dalam konteks makanan halal, hukum syarak telah menetapkan orang Islam diperintahkan oleh Allah SWT untuk memakan atau menggunakan yang halal dan meninggalkan yang haram. Sementara perkara yang menjadi keraguan, iaitu syubhah (samar-samar) perlu ditinggalkan bagi memelihara umat Islam daripada terlibat dengan perkara haram. Perkara ini jelas dinyatakan dalam hadis Rasulullah SAW yang bermaksud:

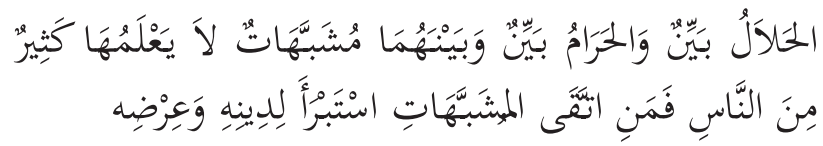

7 Noraziah Ali dan Mohd Azlan Abdullah, "The Food Consumption and Eating Behaviour of Malaysian Urbanities: Issues and Concerns," Malaysia Journal of Society and Space 8, no. 6 (2012), 157-165.

8 Yūsuf al-Qaraḍāwī, al-Halāl wa al-Harām fì al-Islām (Bayrūt: alMaktab al-Islāmī, 1985), 18. 
"Sesungguhnya yang halal itu jelas dan yang haram itu jelas. Manakala, di antara keduanya ada hal-hal syubhah (samar-samar) yang ramai tidak mengetahuinya, maka sesiapa yang menjauhinya, maka dia telah menjaga agama dan kehormatannya." 9

Makanan halal menurut Mazhab Syāfi'iyah adalah semua tumbuhan yang boleh dimakan melainkan tumbuhan yang tercemar, memudaratkan dan mengkhayalkan. Seterusnya, semua haiwan laut adalah halal melainkan haiwan yang dilarang dibunuh dan beracun. Selain itu, haiwan jinak yang dibenarkan adalah haiwan ternakan seperti lembu dan kambing, manakala haiwan liar seperti rusa dan semua jenis burung dihalalkan makan dengan syarat bukan haiwan pemangsa dan tidak mempunyai kuku yang mencengkam. ${ }^{10}$ Seterusnya, makanan yang tidak dinyatakan secara jelas oleh syarak, hendaklah merujuk kepada cita rasa orang Arab. ${ }^{11}$ Hal ini bermakna, makanan tersebut perlu dikenal pasti sama ada ianya tergolong dalam kategori baik atau buruk menurut perspektif Islam. ${ }^{12}$ Kaedah penentuan hukum tersebut melalui istiqra' dan 'uruf sebagaimana Imam al-Syafi'i menilai makanan yang baik adalah apa yang dimakan oleh orang Arab,

9 Muhammad bin Isma'il Abu 'Abd Allah al-Bukhari al-Ja'fi, Sahih alBukhari, bab Fadl man Istabraa Lidinih, no. hadith 2051 (Damshiq: Dar Tuq al-Najah, 1422M), 53.

10 Al-Shairazi, al-Muhazzab fi Fiqh al-Imam al-Syafi 'i (t.tp.: t.p., 1959) 1:253-258. Lihat juga, Mustafa Sa'id al-Khin, Mustafa al-Bagha dan 'Ali al-Syarbiji, al-Figh al-Manhaji 'ala Madhhab al-Imam alSyafi i (Bayrut: Dar al-Qalam, 1992), 3:67-71.

11 Ibid. Lihat juga, Wahbah Zuhayli, al-Figh al-Islami wa Adillatuhu, ed. ke-3 (Dimashq: Dar al-Fikr, 1989), 3: 513.

12 Mohd Anuar Ramli dan Mohammad Aizat Jamaludin, "Kriteria Makanan yang Baik dan Buruk menurut Perspektif Kepenggunaan Islam," dalam Halal Haram dalam Kepenggunaan Islam Semasa, ed. Suhaimi Ab Rahman (Serdang: Penerbit Universiti Putra Malaysia, 2011), 65-83. 
manakala makanan buruk adalah apa yang tidak dimakan oleh orang Arab. ${ }^{13}$

Antara garis panduan untuk menentukan takrifan konsep makanan halal adalah seperti yang dinyatakan dalam MS 1500:2019. Makanan halal dapat didefinisikan sebagai makanan yang dibenarkan di bawah undang-undang Syariah dan memenuhi syarat-syarat berikut: ${ }^{14}$

a) Tidak mengandungi apa-apa bahan daripada haiwan yang tidak halal kepada orang Islam mengikut hukum syarak atau produk daripada haiwan yang tidak disembelih mengikut hukum syarak dan fatwa.

b) Tidak mengandungi najis mengikut hukum syarak dan fatwa.

c) Tidak memabukkan mengikut hukum syarak dan fatwa.

d) Tidak mengandungi mana-mana bahagian atau anggota manusia atau hasilan daripadanya yang tidak dibenarkan oleh hukum syarak.

e) Tidak beracun atau memudaratkan kesihatan.

f) Tidak disediakan, diproses atau di kilang menggunakan peralatan yang dicemari najis mengikut hukum syarak.

g) Semasa penyediaan, pemprosesan, pembungkusan, penyimpanan atau pengangkutan, makanan tersebut diasingkan dari makanan lain yang tidak menepati keperluan dalam butiran 3.4 (a) dan (b).

13 Tuan Sidek Tuan Muda dan Ridzwan Ahmad, "Halal Haram Makanan menurut Imam Syafi'i: Analisis dari Perspektif Maqasid Al-Shari'ah" (Kertas Prosiding, 1st International Conference on Islam and Contemporary Issues in The Islamic World: Challenges and Way Forward (ICIC-2016), Universiti Malaya, 5-6 Disember 2016).

14 Jabatan Standard Malaysia, MS 1500:2019 Makanan Halal: Pengeluaran, Penyediaan, dan Penyimpanan-Garis Panduan Umum (Semakan Kedua) (Putrajaya: Jabatan Standard Malaysia, 2019), 1-2. 
Menurut Khairudin Shaary, ${ }^{15}$ makanan yang halal adalah makanan yang mengandungi beberapa elemen seperti berikut:

a) Semua kandungan daripada bahan-bahan halal. Semua isi kandungan hendaklah terdiri daripada bahan-bahan halal dimakan atau digunakan oleh Muslim serta tidak bercampur dengan sebarang najis, digunakan atau mengandungi unsur najis.

b) Peralatan suci dan bersih daripada najis. Semua peralatan yang digunakan untuk penyediaan, pemprosesan, pengilangan, pembungkusan dan pemasaran makanan dan minuman hendakah tidak terdiri dan bebas (suci) daripada benda-benda kotor dan najis.

c) Pengendalian dan penyimpanan tidak bercampur. Cara pengendalian seperti penyimpanan penghidangan, pembungkusan atau berdekatan dengan benda-benda yang haram dimakan atau digunakan oleh orang Islam.

d) Sumber dan cara perolehan adalah halal. Makanan dan minuman hendaklah diperoleh daripada rezeki atau pendapatan atau punca yang halal serta perolehan yang sah iaitu tidak merompak, mencuri, merampas, menipu dan sebagainya.

Manakala, makanan yang baik (tayyib) pula mengandungi beberapa elemen seperti berikut:

a) Halal, bersih dari segi fizikal, bau dan zatnya. Islam melarang umatnya memakan makanan yang bersumberkan sesuatu yang kotor dan memudaratkan.

b) Hasil sembelihan yang sah. Setiap binatang yang halal dimakan hendaklah disembelih terlebih dahulu sebelum dimakan, kecuali yang tidak disyarakkan untuk disembelih seperti haiwan akuatik hanya sembelihan yang sah kerana Allah SWT sahaja yang halal dimakan.

c) Berkhasiat. Makanan yang berkhasiat ialah makanan yang baik untuk kesihatan jasmani dan rohani.

15 Khairudin Shaary, Halalan Thayyiban: Amalan dan Rukhsah dalam Pemakanan (Kuala Lumpur: Telaga Biru Sdn. Bhd, 2013), 55-57. 
d) Makanan yang segar dan baharu.

e) Sumber yang sah.

f) Sesuai dengan diri individu

Berdasarkan kepada perbincangan ini, pemakanan halālan tayyiban apabila dikaitkan dengan makanan, yang dihalalkan oleh Allah SWT. Makanan dapat memberikan kebaikan dan kesihatan kepada manusia sama ada daripada sudut fizikal, mental, emosi, dan spiritual. Makanan halal dijamin kebersihan dan kesuciannya serta tidak mengandungi unsur-unsur syubhah dan dosa sama ada daripada sudut sumber perolehan, pemprosesan dan penyediaan. Individu Muslim disarankan supaya sentiasa berhati-hati dalam soal pengambilan makanan dengan mengutamakan dua unsur penting iaitu halal dan baik.

\section{METODOLOGI KAJIAN}

Metodologi merupakan aspek yang penting dalam sesuatu kajian. Kajian ini menggunakan kajian perpustakaan berdasarkan metode dokumentasi bagi mengumpul data kajian. Beberapa kajian lepas seperti artikel, tesis, kertas seminar dan bab buku telah dirujuk. Pengumpulan data lebih memfokuskan kajian kuantitatif berbanding kajian kualitatif. Hal ini kerana, kelebihan kajian kuantitatif dalam membuat generalisasi sesuatu populasi. ${ }^{16}$ Hasil dapatan pengumpulan data dianalisis secara induktif dengan mengkhususkan data yang bersifat umum. ${ }^{17}$ Kajian ini menganalisis persamaan, perbezaan dan perkaitan dapatan, seterusnya, menyimpulkan dapatan tersebut kepada beberapa subtopik.

16 Andre Queiros, Daniel Faria dan Fernando Almeida, "Strengths and Limitations of Qualitative and Quantitatives Research Methods," European Journal of Education Studies 3, no. 9 (2017), 369-387.

17 Edwin A. Locke, "The Case for Inductive Theory Building," Journal of Management 33, no. 6 (2007), 867-890. 


\section{SOROTAN LITERATUR BERKAITAN FAKTOR PEMILIHAN PREMIS MAKANAN DALAM KALANGAN MUSLIM}

Pelbagai perancangan telah dirangka dan usaha telah digiatkan dalam perkembangan pensijilan halal di Malaysia. Usaha ini terdiri daripada pelbagai sama ada pihak kerajaan, badan berkewajipan mahupun para cendekiawan dan orang awam bagi menjadikan Malaysia sentiasa kehadapan dalam industri halal. Namun begitu, isu-isu halal sering menjadi perbincangan hangat dan tidak berkesudahan dalam kalangan Muslim. Antaranya, isu yang viral dalam media massa ialah terdapat masyarakat Muslim tidak menitikberatkan pemilihan premis makanan untuk makanan mereka. ${ }^{18}$ Oleh itu, satu kajian literatur diperlukan bagi mendapatkan gambaran secara umum tentang isu dan senario pengguna terhadap pemilihan premis makanan dalam kalangan pengguna Muslim. Berdasarkan beberapa kajian lepas, kajian tentang pemilihan makanan merupakan salah satu cara bagi mendapatkan gambaran umum terhadap pemilihan premis makanan.

Kajian terdahulu menunjukkan teori di dalam metode kuantitatif telah digunakan bagi mengenal pasti tingah laku manusia yang bersifat kompleks. Antara teori yang banyak digunakan dalam kajian terdahulu adalah Theory Planned of Behavior (TPB). Malah, terdapat kajian lepas mencadangkan TPB sebagai model yang berkesan untuk tujuan pembelian makanan dalam kalangan pengguna di Malaysia. ${ }^{19}$ Antara kajian lepas berkaitan pemilihan pemakanan halal yang menggunakan teori TPB adalah kajian oleh Aiedah Abdul Khalek, ${ }^{20} \mathrm{NH}$ Marmaya, Za Zakaria dan Mohd

18 Muhammad Basir Roslan dan Bernama, "Tangani Segera Isu Salah Guna Sijil Halal Sebelum Parah," laman sesawang MalaysiaKini, dicapai 9 Jun 2020, https://www.malaysiakini.com/news/463637.

19 Syed Shah Alam dan Nazura Sayuti, "Applying the Theory of Planned Behavior (TPB) in Halal Food Purchasing," International Journal of Commerce and Management 21, no. 1 (2011), 8-20.

20 Aiedah Abdul Khalek, "Young Consumers' Attitude towards Halal Food Outlets and JAKIM's Halal Certification in Malaysia," Procedia-Social and Behavioral Sciences 121 (2014) 26-34. 
Nasir Mohd Desa, ${ }^{21}$ Khairi Mohamed Omar et al., ${ }^{22}$ Muhammad Abdul Adib Abdul Aziz et al. ${ }^{23}$ dan Ira Eka Pratiwi. ${ }^{24}$ Justeru, kajian literatur ini mengupas faktor pemilihan premis makanan dengan memfokuskan kepada kajian pemilihan makanan yang menggunakan teori TPB dan beberapa kajian lain yang dapat membantu dalam memahami pemilihan premis makanan dalam kalangan pengguna Muslim. Antara faktor tersebut adalah sikap, norma subjektif, kawalan gelagat ditanggap, keagamaan, pensijilan halal, faktor demografi, budaya, kualiti perkhidmatan premis makanan dan sifat makanan.

\section{Sikap}

Sikap merupakan salah satu cara untuk memahami pemilihan makanan dan premis makanan. Berdasarkan teori TPB, terdapat tiga pengukur tingkah laku iaitu sikap, norma subjektif dan kawalan gelagat ditanggap. Sikap bermaksud penilaian seseorang dalam melaksanakan atau tidak sesuatu tingkah laku yang baik atau buruk. ${ }^{25}$ Oleh itu, kepercayaan seseorang individu boleh membawa kepada kepada sikap tertentu. Kajian Aiedah Abdul

$21 \quad$ NH Marmaya, Za Zakaria dan Mohd Nasir Mohd Desa, "Gen Y Consumers' Intention to Purchase Halal Food in Malaysia: a PLSSEM Approach," Journal of Islamic Marketing 10, no. 3 (2019), 1003-1014.

22 Khairi Mohamed Omar et al., "The Direct Effects of Halal Product Actual Purchase Antecedents among the International Muslim Consumers," American Journal of Economics, Special Issue (2012), 87-92.

23 Muhammad Abdul Adib Abdul Aziz et al., "The Influence of Theory of Planned Behavior, Religion and Halal Certification on Consumers' Purchase Intention of Halal Food at Restaurant in Subang Jaya," dalam Contemporary Management and Science Issue in the Halal Industry, ed. Faridah Hassan (Singapura: Springer Nature Singapore Pte Ltd, 2019).

24 Ira Eka Pratiwi, "Halal Food and Young Muslims' Purchase Intention in Indonesia: A Case Study in Papua Province," International Journal of Islamic Economics and Finance Studies 4, no. 3 (2018), 21-34.

25 Icek Ajzen dan Martin Fishbein, Understanding Attitudes and Predicting Social Behavior (Amerika Syarikat: Prentice-Hall Englewood Cliffs, 1980), 54. 
Khalek $^{26}$ mendapati golongan muda bersikap positif terhadap produk makanan halal dan produk yang mempunyai pensijilan halal JAKIM. Kajian tersebut dijalankan terhadap pelajar Muslim yang berumur 16 hingga 35 tahun daripada institusi pengajian tinggi swasta. Namun, ini berbeza terhadap kajian lain pada tahun 2019 yang melibatkan 110 pengguna generasi Y di Malaysia, mendapati sikap tidak memberi kesan kehendak pengguna Gen Y untuk membeli makanan halal di Malaysia. Kajian tersebut menggunakan pendekatan PLS-SEM sebagai alat pengukuran. ${ }^{27}$ Selain itu, Zamra Deraman, Nur Athirah Mohd Borkhan dan Yasinah Abdul Rahman ${ }^{28}$ mendapati terdapat hubungan signifikan antara sikap dan niat pengguna untuk makan di restoran yang mempunyai pensijilan halal. Kajian ini yang dijalankan terhadap 113 penjawat awam dan pegawai industri. Bahkan, Nurul Syuhada Mohd Yunus et al. ${ }^{29}$ mendapati sikap memberi pengaruh terhadap kehendak pengguna Muslim untuk membeli produk yang telah ditarik dan diberi pensijilan halal.

Terdapat juga kajian pemilihan makanan yang menggabungkan responden golongan Muslim dan bukan Muslim, antaranya Syed

26 Aiedah Abdul Khalek, "Young Consumers' Attitude towards Halal Food Outlets and JAKIM's Halal Certification in Malaysia," Procedia-Social and Behavioral Sciences 121 (2014), 26-34.

27 NH Marmaya, Za Zakaria dan Mohd Nasir Mohd Desa, "Gen Y Consumers' Intention to Purchase Halal Food in Malaysia: a PLSSEM Approach," Journal of Islamic Marketing 10, no. 3 (2019), 1003-1014.

28 Zamra Deraman, Nur Athirah Mohd Borkhan dan Yasinah Abdul Rahman, "Determinat Factors of Consumers' Intention to Eat at Halal Certified Restaurant" (makalah, Proceedings of 124th The IIER International Conference, Tokyo, Japan, 29-30 September 2017).

29 Nurul Syuhada Mohd Yunus et al., "Predicting Muslim Consumers' Purchase Intention of Previously Retracted and Recertified Halal Products," Journal of Emerging Economies \& Islamic Research 7, no. 1 (2019), 55-64. 
Shah Alam dan Nazura Sayuti ${ }^{30}$ mendapati sikap pengguna terhadap kehendak pembelian makanan halal mempunyai hubungkait yang signifikan dan kajian ini dilakukan terhadap 251 responden yang terdiri daripada Muslim dan bukan Muslim. Menurut Muhammad Abdul Adib Abdul Aziz et al. ${ }^{31}$ sikap juga mempengaruhi pengguna Muslim dan bukan Muslim terhadap niat pembelian makanan halal di restoran sekitar Subang Jaya. Malah bukan itu sahaja, kajian Noor Raudhiah Abu Bakar, Farah Mohd Shahwahid dan Siti Hawa Radin Ekhsan ${ }^{32}$ mendapati pengaruh sikap pengusaha makanan iaitu peniaga trak makanan (food truck) mempunyai kaitan yang signifikan terhadap pensijilan halal.

Beberapa contoh kajian luar Malaysia berkenaan pembelian makanan halal turut mendapati sikap adalah faktor yang mempengaruhi kehendak pembelian. Menurut Ira Eka Pratiwi ${ }^{33}$ sikap mempengaruhi kehendak pengguna untuk membeli makanan halal di Papua Province, Indonesia. Seterusnya, Reham I. Elseidi ${ }^{34}$ mendapati sikap turut memberi pengaruh terhadap niat pembelian halal. Kajian yang dijalankan terhadap 400 orang Arab Muslim yang menetap di Scotland. Justeru, berdasarkan beberapa kajian lepas yang menggunakan teori TPB jelas mendapati sikap mempunyai kaitan terhadap kehendak pengguna dalam

$30 \quad$ Syed Shah Alam dan Nazura Sayuti, "Applying the Theory of Planned Behavior (TPB) in Halal Food Purchasing", International Journal of Commerce and Management 21, no. 1 (2011), 8-20.

31 Muhammad Abdul Adib Abdul Aziz et al., "The Influence of Theory of Planned Behavior, Religion and Halal Certification on Consumers' Purchase Intention of Halal Food at Restaurant in Subang Jaya," dalam Contemporary Management and Science Issue in the Halal Industry, ed. Faridah Hassan (Singapura: Springer Nature Singapore Pte Ltd, 2019).

32 Noor Raudhiah Abu Bakar, Farah Mohd Shahwahid dan Siti Hawa Radin Eksan, "Theory of Planned Behavior and Halal Compliance," International Journal of Academic Research in Business and Social Science 8, no. 5 (2018), 816-829.

33 Ira Eka Pratiwi, "Halal Food and Young Muslims' Purchase Intention in Indonesia: A Case Study in Papua Province," International Journal of Islamic Economics and Finance Studies 4, no. 3 (2018), 21-34.

34 Reham I. Elseidi, "Determinats of Halal Purchasing Intentions: Evidences from UK," Journal of Islamic Marketing 9, no. 1 (2018), 167-190. 
pemilihan premis makanan. Bahkan, sedikit sahaja hasil kajian menyimpulkan sikap tidak memberi pengaruh terhadap kehendak pemilihan pengguna.

\section{Norma Subjektif}

Norma subjektif turut berperanan dalam mempengaruhi faktor pemilihan makanan. Ia merupakan konstruk kedua dalam TPB yang mempengaruhi kehendak serta tingkah laku manusia. ${ }^{35}$ Norma subjektif ialah pengaruh sosial yang boleh menyebabkan tingkah laku berlaku. Ini merujuk kepada persepsi individu tersebut terhadap pandangan orang penting dalam hidupnya, sama ada individu tersebut perlu atau tidak melaksanakan sesuatu tingkah laku. Hal ini kerana berdasarkan teori ini, semakin ramai orang yang penting dalam hidup individu tersebut berfikir bahawa dia perlu untuk melaksanakan sesuatu tingkah laku, maka semakin tinggi keinginan individu tersebut untuk melaksanakan sesuatu tingkah laku. ${ }^{36}$ Sikap dan norma subjektif mempunyai hubung kait yang positif dalam tingkah laku, ini kerana kebanyakan manusia berkelakuan berdasarkan pandangan orang yang penting di sekelilingnya. ${ }^{37}$

Hal ini boleh dibuktikan, norma subjektif memberi pengaruh terhadap kehendak pengguna Gen Y untuk membeli makanan halal di Malaysia. ${ }^{38}$ Tambahan lagi, kajian Noor Afazainiza Afendi, Farah Lina Azizan dan Afiah Isa Darami ${ }^{39}$ terhadap 100 orang responden secara rawak di Perlis mendapati norma subjektif

35 Icek Ajzen dan Martin Fishbein, Understanding Attitudes and Predicting Social Behavior (Amerika Syarikat: Prentice-Hall Englewood Cliffs, 1980), 57.

36 Ibid.

37 Ibid., 58.

38 NH Marmaya, Za Zakaria dan Mohd Nasir Mohd Desa, "Gen Y Consumers' Intention to Purchase Halal Food in Malaysia: a PLSSEM Approach," Journal of Islamic Marketing 10, no. 3 (2019), 1003-1014.

39 Noor Afazainiza Afendi, Farah Lina Azizan dan Afiah Isa Darami, "Determinants of Halal Purchase Intention: Case in Perlis," International Journal of Business and Social Research (IJBSR) 4, no. 5 (2014), 118-123 
mempunyai impak yang positif terhadap kehendak pengguna membeli produk yang halal dan begitu juga kajian terhadap kehendak pengguna untuk makan di kedai yang mempunyai pensijilan halal turut dipengaruhi oleh norma subjektif. ${ }^{40}$ Malah, Syed Shah Alam dan Nazura Sayuti ${ }^{41}$ mendapati tekanan daripada sosial boleh mempengaruhi sikap responden Muslim dan bukan Muslim untuk membeli produk makanan halal.

Noor Raudhiah Abu Bakar, Farah Mohd Shahwahid dan Siti Hawa Radin Ekhsan ${ }^{42}$ turut mendapati norma subjektif peniaga trak makanan (food truck) mempunyai kaitan yang signifikan positif terhadap pensijilan halal. Namun, terdapat juga norma subjektif tidak mempengaruhi sikap golongan pemuda terhadap kedai makan dan pensijilan halal di Malaysia. ${ }^{43}$ Oleh itu, norma subjektif mempengaruhi pemilihan makanan dalam kalangan Muslim mahupun bukan Muslim dan kajian yang mendapati norma subjektif tidak mempunyai pengaruh yang signifikan terhadap pemilihan makanan adalah kurang.

\section{Kawalan Gelagat Ditanggap}

Kawalan gelagat ditanggap merupakan konstruk ketiga dalam teori TPB. Menurut Ajzen, kebiasaannya sesuatu tingkah laku bergantung kepada keinginan sukarela individu tersebut, namun kadang kala sesuatu tingkah laku boleh jadi terbentuk

40 Zamra Deraman, Nur Athirah Mohd Borkhan dan Yasinah Abdul Rahman, "Determinat Factors of Consumers' Intention to Eat at Halal Certified Restaurant" (makalah, Proceedings of 124th The IIER International Conference, Tokyo, Japan, 29-30 September 2017).

41 Syed Shah Alam dan Nazura Sayuti, "Applying the Theory of Planned Behavior (TPB) in Halal Food Purchasing," International Journal of Commerce and Management 21, no. 1 (2011), 8-20.

42 Noor Raudhiah Abu Bakar, Farah Mohd Shahwahid dan Siti Hawa Radin Eksan, "Theory of Planned Behavior and Halal Compliance," International Journal of Academic Research in Business and Social Science 8, no. 5 (2018), 816-829.

43 Aiedah Abdul Khalek, "Young Consumers' Attitude towards Halal Food Outlets and JAKIM's Halal Certification in Malaysia," Procedia-Social and Behavioral Sciences 121 (2014), 26-34. 
berdasarkan faktor bukan keinginan individu tersebut. ${ }^{44}$ Kawalan gelagat ditanggap sebagai perasaan senang atau susah hendak melaksanakan satu kelakuan. Penilaian dibuat mencerminkan kepada pengalaman yang lepas atau halangan yang dijangkakan. Semakin positif sikap, norma subjektif dan kawalan gelagat ditanggap, maka semakin kuat kecenderungan seseorang untuk melakuan sesuatu tingkah laku. ${ }^{45}$

Berdasarkan teori TPB, sesuatu tingkah laku bermula daripada kepercayaan, maka kepercayaan terhadap kawalan gelagat ditanggap dinamakan pengawalan kepercayaan (control belief). Kepercayaan ini berdasarkan kepada pengalaman yang lepas, pengaruh maklumat daripada pengalaman keluarga atau rakan-rakan dan faktor-faktor lain yang menambahkan atau mengurangkan kesusahan untuk melaksanakan sesuatu tingkah laku. ${ }^{46}$ Kajian lepas juga membuktikan bahawa kawalan gelagat ditanggap mempunyai hubungan antara kehendak pemilihan makanan seperti Khairi Mohamed Omar et al. ${ }^{47}$ Ira Eka Pratiwi, ${ }^{48}$ Norazah Mohd Suki dan Abang Sulaiman Abang Salleh. ${ }^{49}$ Namun, berdasarkan hasil dapatan kajian Mustika Rimadhani, ${ }^{50}$ Zamra

44 Icek Ajzen, "The Theory of Planned Behavior," Organizational Behavior and Human Decision Processes 50, no. 2 (1991), 184.

45 Icek Ajzen dan B.L Driver, "Prediction of Leisure Participation from Behavioral, Normative and Control Belefs: An Application of The Theory of Planned Behavior," Leisure Sciences 13, no. 3 (1991).

46 Icek Ajzen, "The Theory of Planned Behavior," Organizational Behavior and Human Decision Processes 50, no. 2 (1991), 196.

47 Khairi Mohamed Omar et al., "The Direct Effects of Halal Product Actual Purchase Antecedents among the International Muslim Consumers," American Journal of Economics, Special Issue (2012), 87-92.

48 Ira Eka Pratiwi, “Halal Food and Young Muslims' Purchase Intention in Indonesia: A Case Study in Papua Province," International Journal of Islamic Economics and Finance Studies 4, no. 3 (2018), 21-34.

49 Norazah Mohd Suki dan Abang Sulaiman Abang Salleh, "Mediating Effect of Halal Image on Muslim Consumers's Intention to Patronize Retail Stores," Journal Islamic Marketing 9, no. 2 (2018), 338-356.

50 Mustika Rimadhani, Lukman M Baga dan Sahara, "Analysis on Muslim Consumer Behavior toward the Halal Certification of Bakery Products," International Journal of Science and Research 6, no. 7 (2017), 1226-1230. 
Deraman $^{51}$ dan Reham I. Elseidi ${ }^{52}$ mendapati kawalan gelagat ditanggap tidak memberi kesan terhadap kehendak individu kajian. Justeru, hipotesis awal menunjukkan kawalan gelagat ditanggap boleh berperanan dalam membentuk sesetengah kepercayaan kepada pemilihan premis makanan.

\section{Keagamaan}

Beberapa kajian terdahulu mendapati pemilihan premis makanan dipengaruhi oleh sifat dan nilai keagamaan. Antaranya kajian Norazamimah Bogal $^{53}$ mendapati golongan yang mempunyai sifat keagamaan yang tinggi, lebih prihatin terhadap logo halal ketika membeli makanan dan minuman. Kajian beliau dilakukan terhadap 224 penduduk Melayu Muslim yang berada di Lembah Klang. Malah kajian tersebut senada dengan kajian yang telah dikemukakan oleh Burhan Adam ${ }^{54}$ iaitu sifat keagamaan yang tinggi dalam masyarakat Muslim membawa kepada kecenderungan yang tinggi untuk memilih bukan sahaja restoran halal, malah restoran yang kelihatan halal. Kajian dijalankan terhadap 400 penduduk di Lembah Klang. Hal ini juga boleh dikaitkan dengan nilai keagamaan seperti imej halal memberi kesan terhadap niat pengguna untuk sentiasa mengunjungi kedai runcit. ${ }^{55}$

51 Zamra Deraman, Nur Athirah Mohd Borkhan dan Yasinah Abdul Rahman, "Determinant Factors of Consumers' Intention to Eat at Halal Certified Restaurant" (makalah, Proceedings of 124th The IIER International Conference, Tokyo, Japan, 29-30 September 2017).

52 Reham I. Elseidi, "Determinats of Halal Purchasing Intentions: Evidences from UK," Journal of Islamic Marketing 9, no. 1 (2018), 167-190.

53 Norazamimah Bogal, "Religiosity and Halal Food: Attitude of Urban Malay Muslim Consumers" (tesis sarjana, Universiti Malaya, Kuala Lumpur, 2007).

54 Burhan Adam, "Consumer Behavior and Religiosity of Muslim Community in Klang Valley: Consumer Perception on Halal \& Non Halal in Products and Service" (tesis sarjana, Universiti Malaya, Kuala Lumpur, 2000).

55 Norazah Mohd Suki dan Abang Sulaiman Abang Salleh, "Mediating Effect of Halal Image on Muslim Consumers's Intention to Patronize Retail Stores," Journal Islamic Marketing 9, no. 2 (2018), 338-356. 
Bahkan, Aiedah Abdul Khalek ${ }^{56}$ mendapati sifat keagamaan mempengaruhi generasi Y untuk membeli makanan halal. Kajian dijalankan terhadap 452 responden di lima buah institut pengajian tinggi swasta yang berada di Lembah Klang. Muhammad Abdul Adib Abdul Aziz et al. ${ }^{57}$ turut mendapati keagamaan mempengaruhi kehendak pengguna terhadap pembelian makanan halal di restoran sekitar Subang Jaya. Malah, kajian Golnaz Rezai et al. ${ }^{58}$ membuktikan bahawa masyarakat yang mempunyai latar belakang pendidikan sekolah agama dan mempunyai sifat keagamaan yang tinggi lebih prihatin terhadap kesahihan logo halal produk makanan berbanding masyarakat yang tidak berpendidikan sekolah agama dan mempunyai sifat keagamaan yang rendah. Kajian Nor Aini Idris dan Mohd Ali Mohd Noor ${ }^{59}$ juga mendapati nilai indeks keprihatinan pengguna Muslim terhadap isu halal-haram produk berada pada tahap melebihi $50 \%$ iaitu melebihi paras normal dan ini menunjukkan tahap indeks keprihatinan pengguna Muslim terhadap isu halal haram sangat baik.

56 Aiedah Abdul Khalek, "Determinants Influencing Halal Food Consumption among Generation Y Muslims in Malaysian Private Universities" (tesis kedoktoran, Universiti Malaya, Kuala Lumpur, 2015).

57 Muhammad Abdul Adib Abdul Aziz et al., "The Influence of Theory of Planned Behavior, Religion and Halal Certification on Consumers' Purchase Intention of Halal Food at Restaurant in Subang Jaya," dalam Contemporary Management and Science Issue in the Halal Industry, ed. Faridah Hassan (Singapura: Springer Nature Singapore Pte Ltd, 2019).

58 Golnaz Rezai et al., "Concerns for Halalness of Halal Labelled Food Product among Muslim Consumers in Malaysia: Evaluation of Selected Demographic Factors," Economic and Technology Management Review 24 (2009), 65-73.

59 Nor Aini Idris dan Mohd Ali Mohd Noor, "Analisis Keprihatinan Pengguna Muslim terhadap Isu Halal-Haram Produk melalui Pembentukan Indeks" (artikel, Persidangan Kebangsaan Ekonomi Malaysia ke VIII, Johor Bahru, 7-9 Jun 2013). 
Namun, Golnaz Rezai et al. ${ }^{60}$ mempunyai hasil dapatan yang berbeza berbanding pada tahun 2009 iaitu golongan yang mempunyai sifat keagamaan tinggi adalah kurang berkeyakinan terhadap produk makanan yang mempunyai pensijilan halal. Mungkin, hal ini boleh dikaitkan bahawa masyarakat yang mempunyai sifat keagamaan tinggi dan prihatin terhadap kesahihan logo halal menyebabkan mereka bersikap kurang berkeyakinan terhadap produk yang mempunyai pensijilan halal. Tambahan, artikel yang ditulis oleh Nur Aniza Quantanih, Noreina dan Nurul Syakinah $^{61}$ mendapati masyarakat Muslim memilih makanan halal disebabkan oleh tuntutan agama, namun masyarakat bukan Muslim memilih makanan halal disebabkan oleh faktor kesihatan. Justeru, keagamaan merupakan salah satu faktor dalam pemilihan premis dan makanan halal. Malah, makanan dan premis yang mempunyai nilai keagamaan merupakan antara faktor pemilihan makanan dalam kalangan pengguna Muslim.

\section{Pensijilan dan Logo Halal}

Antara faktor pemilihan makanan kerana ianya mempunyai pensijilan dan logo halal. Hal ini boleh dibuktikan menerusi kajian Rika Terano dan Zainalabidin Mohamed $^{62}$ mendapati 143 responden daripada 207 Muslim yakin untuk membeli makanan Jepun yang mempunyai sijil halal Jepun. Kajian ini dikhususkan Muslim di Selangor. Namun, hanya 69 daripada 207 pengguna Muslim prihatin terhadap isu kolaborasi Jabatan Kemajuan Islam Malaysia (JAKIM) dan pensijilan halal Jepun. Malah, Siti

60 Golnaz Rezai, Zainalabidin Mohamed dan Mad Nasir Shamsudin, "Assesments of Consumers' Confidence on Halal Labelled Manufactured Food in Malaysia," Pertanika Journal of Social Science \& Humanities 20, no. 1 (2012) 33-42.

61 Nur Aniza Quantanih, Noreina dan Nurul Syakinah, "Selecting Halal Food: A Comparative Study of The Muslim and non-Muslim Malaysian Student Consumer" (artikel, International Conforence on Technology Management, Bussiness and Entreprenuship, Melaka, 5 Disember 2013).

62 Rika Terano dan Zainalabidin Mohamed, "Malaysian Muslim Consumers' Confidence in Purchasing Japanese Food Products in Selangor," Japanese Journal of Agricultural Economics 19 (2017) 43-47. 
Fatimah Hamidon dan Hidayat Buang ${ }^{63}$ menjangkakan bahawa kebanyakan pengguna Muslim prihatin terhadap keutamaan dan kepentingan produk yang mempunyai logo halal JAKIM. Hal ini merujuk kepada sorotan literatur pandangan pengguna Muslim terhadap pemakaian logo halal Jabatan Kemajuan Islam Malaysia (JAKIM). Zul Ariff Abdul Latiff et al. ${ }^{64}$ mendapati terdapat maklum balas yang positif antara kehendak pengguna dengan aplikasi sistem pelabelan halal secara talian. Tambahan lagi, hasil kajian Zaimah Ramli et al. ${ }^{65}$ mendapati kebanyakan pengguna bersetuju bahawa status logo halal perlu untuk membuktikan sesuatu produk tersebut halal. Bahkan kajian ini disokong oleh Norrina Din et al. ${ }^{66}$ yang mendapati pelajar lebih berhati-hati dalam memilih makanan halal dan mereka lebih yakin produk makanan yang mempunyai logo halal JAKIM.

Namun, kajian Muhammad Abdul Adib Abdul Aziz et al. ${ }^{67}$ mendapati pensijilan halal memberi pengaruh paling sedikit antara pengukur lain seperti sikap, norma subjektif dan keagamaan terhadap pemilihan restoran di sekitar Subang Jaya. Kajian Golnaz

63 Siti Fatimah Hamidon dan Hidayat Buang, "Pandangan Pengguna Muslim terhadap Pemakaian Logo Halal Jabatan Kemajuan Islam Malaysia (JAKIM): Satu Sorotan Literatur,” Journal of Shariah Law Research 1, no. 1 (2016) 105-118.

64 Zul AriffAbdul Latiff et al., "Application of Onlie Halal Label among Consumer Intention toward the Halal Label System in Malaysia", Borneo Jurnal of Sciences and Technology 1, no. 1 (2019), 15-20.

65 Zaimah Ramli et al., "Malaysia sebagai Pusat Halal Global: Satu Penemuan Awal mengenai Persepsi Halal dalam Kalangan Pengguna di Malaysia," Malaysian Journal of Society and Space 10, no.6 (2014) 48-56.

66 Norrina Din et al., "Gauging Students' Perception and Attitudes towards Halal Products and Logos," dalam Heritage, Culture and Society, ed. Radzi et al. (London: Taylor \& Francis Group, 2016).

67 Muhammad Abdul Adib Abdul Aziz et al., "The Influence of Theory of Planned Behavior, Religion and Halal Certification on Consumers' Purchase Intention of Halal Food at Restaurant in Subang Jaya," dalam Contemporary Management and Science Issue in the Halal Industry, ed. Faridah Hassan (Singapura: Springer Nature Singapore Pte Ltd, 2019). 
Rezai, Zainalabidin Mohamed dan Mad Nasir Shamsudin ${ }^{68}$ pula menunjukkan bahawa kebanyakan masyarakat Malaysia masih ragu-ragu dan tidak mempunyai keyakinan sepenuhnya terhadap produk makanan yang mempunyai pensijilan halal. Ini juga boleh dikaitkan dengan Haslenna Hamdan et al. ${ }^{69}$ mendapati pengguna Muslim memilih pembelian makanan segera bukan berdasarkan faktor halal, namun faktor kebiasaan membeli makanan tersebut. Responden kajian ini terdiri daripada 400 pengguna Muslim yang membeli belah di pasar raya terpilih di Terengganu.

Perbezaan ini boleh disimpulkan melalui kajian Nordin Ahmad. ${ }^{70}$ Kajian ini mengupas persepsi persatuan pengguna terhadap pengesahan sijil halal JAKIM pada produk-produk halal. Dapatan kajian mendapati keyakinan responden terhadap pensijilan halal JAKIM adalah masih berada pada tahap tinggi. Walau bagaimanapun, tahap keyakinan tersebut tidak konsisten dan berubah-ubah bergantung kepada isu-isu yang timbul dari semasa ke semasa. Kajian ini juga mendapati bahawa responden kurang mempunyai pengetahuan mengenai sumber bahan halal dan cara pemprosesan makanan halal. Dengan keadaan ini, tahap keyakinan terhadap pensijilan halal JAKIM banyak dipengaruhi oleh situasi masa, keadaan masyarakat dan persekitaran kerja. Oleh itu, pensijilan dan logo halal JAKIM memberi pengaruh kepada kebanyakan pengguna Muslim dalam memilih makanan, namun ia turut tidak dipengaruhi dalam beberapa keadaan dan isu.

\section{Faktor Demografi}

Faktor demografi responden yang berbeza menyebabkan berlaku perbezaan dalam pemilihan makanan. Contohnya, perbezaan

68 Golnaz Rezai, Zainalabidin Mohamed dan Mad Nasir Shamsudin, "Assesments of Consumers' Confidence on Halal Labelled Manufactured Food in Malaysia," Pertanika Journal of Social Science \& Humanities 20, no. 1 (2012) 33-42.

69 Haslenna Hamdan et al., "Purchasing Decisions among Muslim Consumers of Processed Halal Food Products," Journal of Food Products Marketing 19, no. 54 (2013), 61.

70 Nordin Ahmad, "Persepsi Persatuan Pengguna di Malaysia terhadap Status Pengesahan Halal Jabatan Kemajuan Islam Malaysia (JAKIM)" (tesis kedoktoran, Jabatan Fiqh dan Usul, Akademi Pengajian Islam, Universiti Malaya, 2007). 
tempat tinggal responden yang berasal dari Pantai Timur Semenanjung Malaysia menunjukkan sikap lebih prihatin terhadap kesahihan produk berlabel halal. ${ }^{71}$ Selain itu, umur berbeza turut mempengaruhi sikap pengguna dalam pemilihan makanan halal. Hal ini merujuk kepada artikel Zuraini, Muhammad Afiq dan Nurzulain $^{72}$ yang mendapati terdapat perbezaan sikap terhadap produk makanan halal antara Gen X, Gen Y dan Gen Z. Hal ini boleh dijelaskan melalui dapatan kajian daripada Aiedah Abdul Khalek et al. ${ }^{73}$ mendapati persepsi majoriti generasi Y sangat mementingkan pensijilan halal dan makanan yang mempunyai pensijilan halal adalah lebih dipercayai. Terdapat kajian juga mendapati golongan orang tua secara khususnya penduduk kampung kurang berkeyakinan terhadap produk makanan yang mempunyai pensijilan halal. ${ }^{74}$ Selain itu, faktor umur dan pendapatan turut memberi pengaruh yang positif terhadap penggunaan aplikasi label halal di Malaysia. ${ }^{75}$

Taraf pendidikan boleh juga menyebabkan berlaku perbezaan faktor pemilihan makanan, ini kerana terdapat kajian dijalankan di beberapa institusi pengajian mendapati makanan yang

71 Golnaz Rezai et al., "Concerns for Halalness of Halal Labelled Food Product among Muslim Consumers in Malaysia: Evaluation of Selected Demographic Factors," Economic and Technology Management Review 24 (2009), 65-73.

72 Zuraini, Muhammad Afiq dan Nurzulain, "The Influence of CrossGeneration Attitude on Halal food Products," Malays Appl. Biol. 48, no. 2 (2019), 41-46.

73 Aiedah Abdul Khalek et al., "With or Without Halal Logo? A Descriptive Analysis of the Generation Y on the National Halal Certification Malaysia" (artikel, Third Asia Pacific Conference on Advanced Research Melbourne, Julai 2016).

74 Golnaz Rezai, Zainalabidin Mohamed dan Mad Nasir Shamsudin, "Assesments of Consumers' Confidence on Halal Labelled Manufactured Food in Malaysia," Pertanika Journal of Social Science \& Humanities 20, no. 1 (2012), 33-42.

75 Zul Ariff Abdul Latiff et al., "Application of Onlie Halal Label among Consumer Intention toward the Halal Label System in Malaysia," Borneo Jurnal of Sciences and Technology 1, no. 1 (2019), 15-20. 
mendapat pensijilan halal lebih diutamakan. ${ }^{76}$ Seterusnya, kajian lain mendapati responden berpendidikan sekolah agama dan mempunyai sifat keagamaan yang tinggi lebih prihatin terhadap kesahihan logo halal produk makanan. ${ }^{77}$ Namun, berbeza pula Golnaz Rezai, Zainalabidin Mohamed dan Mad Nasir Shamsudin mendapati golongan berpendidikan tinggi kurang berkeyakinan terhadap produk makanan yang mempunyai pensijilan halal. ${ }^{78}$ Oleh itu, latar belakang demografi yang berbeza menyebabkan berlaku perbezaan pemilihan makanan.

\section{Budaya}

Budaya merupakan antara faktor pemilihan makanan dalam kalangan pengguna Muslim. Redzuan Muhamad ${ }^{79}$ dalam kajiannya terhadap pelajar sekolah menengah harian di Lahad Datu, Sabah, mendapati terdapat hubungan positif yang signifikan antara pengaruh budaya setempat dan pengetahuan agama terhadap pemilihan makanan halal. Namun pengaruh budaya lebih mendominasi dalam pemilihan makanan halal berbanding pengetahuan agama. Selain itu, antara budaya luar yang mempengaruhi pemilihan makanan dalam kalangan pengguna Muslim adalah budaya Korea. Pengguna Malaysia yang berumur 26 sehingga 35 telah menyumbang 40 peratus daripada jumlah

76 Aiedah Abdul Khalek, "Determinants Influencing Halal Food Consumption among Generation Y Muslims in Malaysian Private Universities" (tesis kedoktoran, Universiti Malaya, Kuala Lumpur, 2015).

77 Golnaz Rezai et al., "Concerns for Halalness of Halal Labelled Food Product among Muslim Consumers in Malaysia: Evaluation of Selected Demographic Factors," Economic and Technology Management Review 24 (2009), 65-73.

78 Golnaz Rezai, Zainalabidin Mohamed dan Mad Nasir Shamsudin, "Assesments of Consumers' Confidence on Halal Labelled Manufactured Food in Malaysia," Pertanika Journal of Social Science \& Humanities 20, no. 1 (2012), 33-42.

79 Redzuan Muhamad, "Pengaruh Budaya Setempat dan Pengetahuan Agama Terhadap Pemilihan Makanan Halal dalam Kalangan Pelajar Sekolah Menengah Harian di Lahad Datu, Sabah" (tesis sarjana, Akademi Pengajian Islam, Universiti Malaya, 2017). 
penjualan makanan Korea pada tahun 2016. ${ }^{80}$ Pengguna Muslim turut tidak ketinggalan untuk merasai hidangan makanan Korea. Artikel yang ditulis oleh Nurul Nabihah Buang et al. ${ }^{81}$ mendapati terdapat beberapa faktor yang menyebabkan pengguna Muslim membeli makanan di restoran Korea. Antaranya disebabkan oleh promosi, kesedaran halal dan norma subjektif. Justeru, pemilihan makanan boleh dipengaruhi oleh sama ada budaya asing mahupun budaya tempatan. Ini boleh dibuktikan peningkatan kepelbagaian premis makanan yang menyediakan makanan jenama antarabangsa seperti makanan Korea, Jepun, India, China, Thailand dan Itali di bandar.

\section{Kualiti Perkhidmatan Premis Makanan}

Menurut Kostas Alexandris et al. menyatakan bahawa tingkah laku manusia boleh diukur melalui kualiti perkhidmatan premis yang disediakan. ${ }^{82}$ Pengguna akan suka untuk mengunjungi premis tersebut apabila kualiti perkhidmatan disediakan mesra pelanggan. Ini boleh membawa kepada faktor pemilihan premis makanan. Kajian tersebut menggunakan teori Zeithman ${ }^{83}$ dalam mengkaji kualiti perkhidmatan iaitu teori SERVQUAL, yang didapati dengan lima perkara antaranya kebolehpercayaan,

80 Zuliantie Dzul, "Korean Wave's Here to Stay", laman sesawang New Straits Times, dicapai 9 Jun 2020, https://www.nst.com.my/ news/2016/11/192393/korean-waves-here-stay.

81 Nurul Nabihah Buang et al., "Muslim Consumers' Patronage Intention towards Korean Restaurant Chains in Malaysia" (artikel, The 6th International Conference on Manufacturing, Optimization, Industrial and Material Engineering, 2018).

82 Kostas Alexandris, Nikos Dimitriadis dan Dimitra Markata, "Can Perceptions of Service Quality Predict Behavioral Intentions? Exploratory Study in the Hotel Sector in Greece," Journal of Service Theory and Practice 12, no. 4 (2002), 224-231.

83 Valarie A. Zeithaml, Leonard L. Berry dan A. Parasuraman, "The Behavioral Consequences of Service Quality," Journal of Marketing 60 (1996), 31-46. 
jaminan, empati, ciri-ciri fizikal dan layanan pelanggan. ${ }^{84}$ SERVQUAL telah digunakan dalam kajian berkaitan premis makanan seperti Lily KoKing Har, ${ }^{85}$ Aidin Namin ${ }^{86}$ dan Gautam Shandilya et al. ${ }^{87}$ Malah, Park Thaichon, Sara Quach dan Jiraporn Surachartkumtonkun ${ }^{88}$ mendapati nilai keseronokan merupakan antara strategi pemasaran iaitu dengan menawarkan pelbagai menu, pemilihan menu dan aktiviti yang menyeronokkan.

Bahkan, artikel yang ditulis oleh Nurul Nabihah Buang et al. ${ }^{89}$ mendapati antara faktor yang menyebabkan pengguna sering berkunjung untuk membeli makanan di restoran Korea adalah kerana hedonic value dan nilai utilitarian (utilitarian value). Hedonic value bermaksud pengalaman baik dan gembira yang diperolehi oleh pengguna selepas membeli sesuatu produk atau servis. Manakala, nilai utilitarian ialah manfaat yang diperolehi oleh pengguna apabila menggunakan servis atau produk tersebut. ${ }^{90}$

84 Konstantinos Alexandris, Nikos Dimitriadis dan Dimitra Markata, "Can Perceptions of Service quality Predict Behavioral Intentions? An Exploratory Study in the Hotel Sector in Greece," Managing Service Quality: An International Journal 12, no. 4 (2002), 224-231.

85 Lily KoKing Har, "Service Dimensions of Service Quality Impacting Customer Satisfaction of Fine Dining Restaurants in Singapore" (tesis sarjana, Universtity of Nevada, Los Vegas, 2008), 686.

86 Aidin Namin, "Revisiting Customers'perception of Service Quality in Fast Food Restaurants," Journal of Retailing and Consumer Services 34 (2017), 70-81.

87 Gautam Shandilya, Saumya Singh dan A.R. Srivastava, "Impact of Consumers' Perception on The Service Quality of Fast-Food Sector," International Journal of Mechanical Engineering and Technology (IJMET) 9, no. 2 (2018), 74-87.

88 Park Thaichon, Sara Quach dan Jiraporn Surachartkumtonkun, "Intention to Purchase at a Fast Food Store: Excitement, Performance and Threshold Attributes," Asian Journal of Business Research 9, no. 1 (2019), 81-101.

89 Nurul Nabihah Buang et al., "Muslim Consumers' Patronage Intention towards Korean Restaurant Chains in Malaysia" (artikel, The 6th International Conference on Manufacturing, Optimization, Industrial and Material Engineering, 2018).

90 Rajeev Batra dan Olli T. Ahtola, "Measuring the Hedonic and Utilitarian Sources of Consumer Attitudes," Marketing Letters 2, no.2 (1990), 159-170. 
Faktor tersebut menyebabkan pengguna akan mengunjungi lagi premis tersebut. ${ }^{91}$ Sarimah Ismai $1{ }^{92}$ juga mendapati servis berkualiti, kemudahan di tempat makan seperti tempat letak kenderaan, surau, tempat selesa dan keadaan staf profesional mempengaruhi kepuasan pelanggan, yang boleh mempengaruhi pelanggan untuk berkunjung semula ke premis tersebut. Kajian dijalankan terhadap tiga buah restoran Melayu dengan menemu bual 108 pengguna yang menikmati makanan di restoran. Kesimpulannya, sistem premis makanan yang efisien dan menawarkan pelbagai manfaat merupakan antara faktor pemilihan makanan dalam kalangan Muslim.

\section{Sifat Makanan}

Selain daripada makanan halal, sifat makanan yang sedap, bersih, berkualiti dan murah turut mempengaruhi pemilihan makanan dalam kalangan Muslim. Beberapa kajian terdahulu seperti yang dilakukan oleh SooCheong (Shawn) Jang et al..$^{93}$ dan Wim Verbeke et al. ${ }^{94}$ turut mendapati faktor citarasa dan menu makanan berperanan penting dalam pemilihan premis makanan. Malah, berdasarkan kajian Sylwia Zakowska-Biemans ${ }^{95}$ mendapati faktor citarasa merupakan faktor paling utama dalam pemilihan makanan, yang kedua faktor harga dan keselamatan juga turut

91 Nurul Nabihah Buang et al., "Muslim Consumers' Patronage Intention towards Korean Restaurant Chains in Malaysia" (artikel, The 6th International Conference on Manufacturing, Optimization, Industrial and Material Engineering, 2018).

92 Sarimah Ismail, "Customer Satisfaction in Malaysian Malay Restaurants Dining Experience" (tesis kedoktoran, University Bournemouth, England, 2012).

93 Soo Cheong (Shawn) Jang, Aejin Ha dan Carol A. Silkes, "Perceived Attributes of Asian Foods: From the Perspective of the American customers," International Journal of Hospitality Management 28, no. 1 (2009), 63-70.

94 Wim Verbeke dan Gisela Poquiviqui López, "Ethnic Food Attitudes and Behaviour among Belgians and Hispanics Living in Belgium," British Food Journal 107, no. 11 (2005), 823-840.

95 Sylwia Zakowska-Biemans, "Polish Consumer Food Choices and Beliefs about Organic Food," British Food Journal 113, no. 1 (2011), 122-137. 
boleh membawa kepada pemilihan makanan.

Di Malaysia, faktor pemilihan citarasa disokong oleh kajian Kartina Abu Bakar terhadap premis makanan mamak. Kajian mendapati aroma di kedai mamak merupakan antara faktor pelanggan menikmati makanan di kedai tersebut. ${ }^{96}$ Selain itu, kajian lain turut mendapati kebanyakan Muslim membeli makanan di luar berdasarkan kepada harga dan rasa. ${ }^{97}$ Seterusnya, terdapat kajian mendapati disebabkan peredaran zaman yang berubah membuatkan rakyat memilih sifat makanan yang berkualiti. ${ }^{98}$ Namun, dalam Islam tidak memadai hanya makanan berkualiti sahaja tetapi makanan tersebut mestilah halal. ${ }^{99}$ Kajian terhadap 201 pelajar di sebuah institut pengajian tinggi mendapati bahawa kebanyakan responden mempunyai kesedaran yang baik mengenai aspek pemakanan yang betul dan sihat. ${ }^{100}$ Oleh itu, sifat makanan yang sedap, murah, bersih merupakan antara faktor pemilihan makanan dalam kalangan pengguna Muslim

96 Kartina Abu Bakar, “Consumers Attitude Towards 'Mamak' Food in Malaysia” (tesis sarjana, Fakulti Perniagaan dan Perakaunan, Universiti Malaya, 2011).

97 Nor Ardyanti Ahmad, Tunku Nashril Tunku Abaidah dan Mohd Helmi Abu Yahya, "A Study on Halal Food Awareness Among Muslim Customers in Klang Valley" (makalah, International Conference on Business and Economic Research in Klang Valley, 4-5 Mac 2013).

98 Irena Ozimek dan Sylwia Zakowska-Biemans, "Determinants of Polish Consumers' Food Choices and Their Implication for the National Food Industry," British Food Journal 113, no. 1 (2011), 138-154.

99 Nor Ardyanti Ahmad, Tunku Nashril Tunku Abaidah dan Mohd Helmi Abu Yahya, "A Study on Halal Food Awareness Among Muslim Customers in Klang Valley" (makalah, International Conference on Business and Economic Research in Klang Valley, 4-5 Mac 2013).

100 Amey Rozalina Azeman, Nurul Farhana Mohd Raduan dan Nur Farhana Othman, "Pemilihan Makanan di Kalangan Pelajar Kolej Universiti Islam Melaka: Satu Tinjauan," Journal of Hospitality and Networks 1 (2016), 71-80. 


\section{SOROTAN LITERATUR PEMILIHAN PREMIS MAKANAN DALAM KALANGAN PENGGUNA MELAYU MUSLIM BANDAR}

Terdapat beberapa kajian lepas berkaitan pemilihan makanan yang memfokuskan di bandar. Antaranya, Muhammad Abdul Adib Abdul Aziz et al., ${ }^{101}$ Burhan Adam ${ }^{102}$ dan Aiedah Abdul Khalek $^{103}$ mendapati nilai keagamaan mempengaruhi pemilihan premis makanan dalam kalangan Melayu Muslim bandar. Malah, pengguna Muslim yang mempunyai keagamaan tinggi cenderung memilih restoran yang kelihatan halal. ${ }^{104}$ Pemilihan makanan yang dipengaruhi oleh keagamaan boleh menandakan keprihatinan dalam mencari makanan halal yang sangat baik dalam kalangan pengguna.

Sikap, norma subjektif dan pensijilan halal turut mempengaruhi pemilihan premis makanan dalam kalangan pengguna Melayu Muslim bandar menurut kajian Aiedah Abdul Khalek et al. ${ }^{105}$ dan

101 Muhammad Abdul Adib Abdul Aziz et al., "The Influence of Theory of Planned Behavior, Religion and Halal Certification on Consumers' Purchase Intention of Halal Food at Restaurant in Subang Jaya," dalam Contemporary Management and Science Issue in the Halal Industry, ed. Faridah Hassan (Singapura: Springer Nature Singapore Pte Ltd, 2019).

102 Burhan Adam, "Consumer Behavior and Religiosity of Muslim Community in Klang Valley: Consumer Perception on Halal \& Non halal in Products and Service" (tesis sarjana, Universiti Malaya, Kuala Lumpur, 2000).

103 Aiedah Abdul Khalek, "Determinants Influencing Halal Food Consumption among Generation Y Muslims in Malaysian Private Universities" (tesis kedoktoran, Universiti Malaya, Kuala Lumpur, 2015).

104 Burhan Adam, "Consumer Behavior and Religiosity of Muslim Community in Klang Valley: Consumer Perception on Halal \& Non Halal in Products and Service" (tesis sarjana, Universiti Malaya, Kuala Lumpur, 2000).

105 Aiedah Abdul Khalek et al., "With or Without Halal Logo? A Descriptive Analysis of the Generation Y on the National Halal Certification Malaysia" (artikel, Third Asia Pacific Conference on Advanced Research Melbourne, Julai 2016). 
Muhammad Abdul Adib Abdul Aziz et al. ${ }^{106}$ Namun begitu, Muhammad Abdul Adib Abdul Aziz et al. mendapati pensijilan halal memberi pengaruh paling sedikit berbanding faktor lain. ${ }^{107}$ Ini boleh dikaitkan dengan kajian Nor Ardyanti Ahmad, Tunku Nashril Tunku Abaidah dan Mohd Helmi Abu Yahya yang mendapati kebanyakan Muslim di Lembah Klang membeli makanan di luar berdasarkan kepada harga dan rasa berbanding terdapat logo halal. ${ }^{108}$ Oleh itu, tidak dinafikan beberapa kajian sarjana telah dijalankan berkaitan persepsi, pemahaman dan pemilihan makanan halal dalam kalangan pengguna Muslim bandar.

\section{KESIMPULAN}

Melalui pengamatan pengkaji, terdapat beberapa perkara boleh disimpulkan daripada kajian terdahulu, antaranya, kajian pemilihan premis makanan pengguna Muslim secara umumnya boleh diklasifikasikan sebagai kajian yang bersifat berubahberubah dan dipengaruhi oleh pelbagai faktor. Secara asasnya pemilihan tersebut dipengaruhi oleh sikap, norma subjektif, kawalan gelagat ditanggap, keagamaan, pensijilan dan logo halal, faktor demografi, budaya, kualiti perkhidmatan premis makanan dan sifat makanan. Faktor pemilihan yang pelbagai ini boleh menimbulkan polemik kerana sambutan usahawan pengusaha makanan bumiputera dalam mendapatkan pensijilan halal adalah kurang memberangsangkan berdasarkan beberapa kajian lepas. Malah, berlaku beberapa isu berkaitan pemilihan premis makanan dalam kalangan pengguna. Pengusaha Muslim seharusnya

106 Muhammad Abdul Adib Abdul Aziz et al., "The Influence of Theory of Planned Behavior, Religion and Halal Certification on Consumers' Purchase Intention of Halal Food at Restaurant in Subang Jaya," dalam Contemporary Management and Science Issue in the Halal Industry, ed. Faridah Hassan (Singapura: Springer Nature Singapore Pte Ltd, 2019).

107 Ibid.

108 Nor Ardyanti Ahmad, Tunku Nashril Tunku Abaidah dan Mohd Helmi Abu Yahya, "A Study on Halal Food Awareness Among Muslim Customers in Klang Valley" (makalah, International Conference on Business and Economic Research in Klang Valley, 4-5 Mac 2013). 
memohon pensijilan halal secara sukarela bagi membantu para pengguna Muslim dalam pemilihan premis makanan. Melalui perlabelan halal JAKIM, pengguna Muslim boleh mengenal pasti dan memilih makanan halālan țayyiban. Malah, prosedur-prosedur yang ditetapkan oleh JAKIM merupakan salah satu cara bagi menerapkan konsep halālan țayyiban di premis makanan. Justeru, beberapa isu berkaitan premis makanan akan berterusan timbul apabila tiada kesatuan dalam meningkatkan tahap pensijilan halal JAKIM, selaku pihak berautoriti mengesah makanan tersedia halal dan tayyiban. Pengguna seharusnya lebih bijak dalam memilih premis makanan yang halal kerana makanan boleh mempengaruhi kelakuan seseorang.

\section{PENGHARGAAN}

Setinggi-tinggi pernghargaan kepada geran penyelidikan Bantuan Kecil Penyelidikan (BKP), Universiti Malaya (UM). Kod Penyelidikan: BK018-2018.

\section{RUJUKAN}

"Pengguna Perlu Lebih Maklumat dalam Isu Halal," laman sesawang mStar, dicapai pada 21 April 2019, http:// www.mstar.com.my/lain-lain/rencana/2010/02/09/ pengguna-perlu-lebih-maklumat-dalam-isuhalal/\#ZdMYXDi2qfU0vw21.99.

Ahmad Faidhi Mohd Sidek, "Permasalahan dalam Permohonan Sijil Halal dalam Kalangan Usahawan Perusahaan Kecil dan Sederhana (PKS) di Malaysia" (tesis sarjana, Akademi Pengajian Islam, Universiti Malaya, 2017).

Aidin Namin, "Revisiting Customers' Perception of Service Quality in Fast Food Restaurants," Journal of Retailing and Consumer Services 34 (2017), 70-81.

Aiedah Abdul Khalek, "Determinants Influencing Halal Food Consumption among Generation Y Muslims in Malaysian Private Universities" (tesis kedoktoran, Universiti Malaya, Kuala Lumpur, 2015). 
Aiedah Abdul Khalek, "Young Consumers' Attitude towards Halal Food Outlets and JAKIM's halal certification in Malaysia," Procedia-Social and Behavioral Sciences 121 (2014), 2634.

Amey Rozalina Azeman, Nurul Farhana Mohd Raduan dan Nur Farhana Othman, "Pemilihan Makanan di Kalangan Pelajar Kolej Universiti Islam Melaka: Satu Tinjauan," Journal of Hospitality and Networks 1 (2016), 71-80.

Andre Queiros, Daniel Faria dan Fernando Almeida, "Strengths and Limitations of Qualitative and Quantitatives Research Methods," European Journal of Education Studies 3, no. 9 (2017), 369-387.

Burhan Adam, "Consumer Behavior and Religiosity of Muslim Community in Klang Valley: Consumer Perception on halal \& non halal in Products and Service" (tesis sarjana, Universiti Malaya, Kuala Lumpur, 2000).

Edwin A. Locke, "The Case for Inductive Theory Building," Journal of Management 33, no. 6 (2007), 867-890.

Gautam Shandilya, Saumya Singh dan A.R. Srivastava, "Impact of Consumers' Perception on The Service Quality of Fast-Food Sector," International Journal of Mechanical Engineering and Technology (IJMET) 9, no. 2 (2018), 74-87.

Golnaz Rezai et al., "Concerns for Halalness of Halal Labelled Food Product among Muslim Consumers in Malaysia: Evaluation of Selected Demographic Factors," Economic and Technology Management Review 24 (2009), 65-73.

Golnaz Rezai, Zainalabidin Mohamed dan Mad Nasir Shamsudin, "Assesments of Consumers' Confidence on Halal Labelled Manufactured Food in Malaysia," Pertanika Journal of Social Science \& Humanities 20, no. 1 (2012), 33-42.

Haslenna Hamdan et al., "Purchasing Decisions among Muslim Consumers of Processed Halal Food Products," Journal of Food Products Marketing 19, no. 54 (2013), 61.

Icek Ajzen dan B.L Driver, "Prediction of Leisure Participation from Behavioral, Normative and Control Belefs: An Application of the Theory of Planned Behavior," Leisure Sciences 13, no. 3 (1991). 
Icek Ajzen dan Martin Fishbein, Understanding Attitudes and Predicting Social Behavior (Amerika Syarikat: PrenticeHall Englewood Cliffs, 1980).

Icek Ajzen, "The Theory of Planned Behavior," Organizational Behavior and Human Decision Processes 50, no. 2 (1991), 184.

Ira Eka Pratiwi, "Halal Food and Young Muslims' Purchase Intention in Indonesia: A Case Study in Papua Province," International Journal of Islamic Economics and Finance Studies 4, no. 3 (2018), 21-34.

Irena Ozimek dan Sylwia Zakowska-Biemans, "Determinants of Polish Consumers' Food Choices and Their Implication for the National Food Industry," British Food Journal 113, no. 1 (2011), 138-154.

Jabatan Standard Malaysia, MS 1500:2019 Makanan Halal: Pengeluaran, Penyediaan, dan Penyimpanan-Garis Panduan Umum (Semakan Kedua) (Putrajaya: Jabatan Standard Malaysia, 20019), 1-2.

Kartina Abu Bakar, 'Consumers Attitude towards 'Mamak' Food in Malaysia" (tesis sarjana, Fakulti Perniagaan dan Perakaunan, Universiti Malaya, 2011).

Khairi Mohamed Omar et al., "The Direct Effects of Halal Product Actual Purchase Antecedents among the International Muslim Consumers," American Journal of Economics, Special Issue (2012), 87-92.

Khairudin Shaary, Halalan Thayyiban: Amalan dan Rukhsah dalam Pemakanan (Kuala Lumpur: Telaga Biru Sdn. Bhd, 2013), 55-57.

Konstantinos Alexandris, Nikos Dimitriadis dan Dimitra Markata, "Can Perceptions of Service quality Predict Behavioral Intentions? An Exploratory Study in the Hotel Sector in Greece," Managing Service Quality: An International Journal 12, no. 4 (2002), 224-231.

Lily KoKing Har "Service Dimensions of Service Quality Impacting Customer Satisfaction of Fine Dining Restaurants in Singapore" (tesis sarjana, Universtity of Nevada, Los Vegas, 2008). 
Mohd Anuar Ramli dan Mohammad Aizat Jamaludin, "Budaya Makanan dan Pemakanan Halal dalam Kalangan Masyarakat Melayu menurut Perspektif Islam," dalam Penyelidikan tentang Makanan: Perspektif Nabawi dan Saintifik, ed. Mohd Yakub@Zulkifli Mohd Yusoff, Khadher Ahmad dan Monika@ Munirah Abd Razzak (Kuala Lumpur: Jabatan Al-Quran dan Al-Hadith, 2016), 195-206.

Mohd Anuar Ramli dan Mohammad Aizat Jamaludin, "Kriteria Makanan yang Baik dan Buruk menurut Perspektif Kepenggunaan Islam," dalam Halal Haram dalam Kepenggunaan Islam Semasa, ed. Suhaimi Ab Rahman (Serdang: Penerbit Universiti Putra Malaysia, 2011), 65-83.

Muhammad Abdul Adib Abdul Aziz et al., "The Influence of Theory of Planned Behavior, Religion and Halal Certification on Consumers' Purchase Intention of Halal Food at Restaurant in Subang Jaya," dalam Contemporary Management and Science Issue in the Halal Industry, ed. Faridah Hassan (Singapura: Springer Nature Singapore Pte Ltd, 2019), 53-63.

Muhammad Basir Roslan dan Bernama, "Tangani Segera Isu Salah Guna Sijil Halal Sebelum Parah," laman sesawang MalaysiaKini, dicapai 9 Jun 2020, https://www. malaysiakini.com/news/463637.

Muhammad bin Isma'il Abu 'Abd Allah al-Bukhari al-Ja'fi, Sahih al-Bukhari, bab Fadl man Istabraa li Dinih, no. hadis 2051 (Damshiq: Dar Tuq al-Najah, 1422M).

Mustafa Sa'id al-Khin, Mustafa al-Bagha dan 'Ali al-Sharbiji, alFiqh al-Manhaji 'ala Madhhab al-Imam al-Syafi' $i$ (Bayrut: Dar al-Qalam, 1992), 3:67-71.

Mustika Rimadhani, Lukman M Baga dan Sahara, "Analysis on Muslim Consumer Behavior toward the Halal Certification of Bakery Products," International Journal of Science and Research 6, no. 7 (2017), 1226-1230.

Nazura Ngah, Hazwan Faisal Mohamad dan Fahmy Azril Rosli, "Pensijilan Halal Malaysia Sukarela, Terbuka Semua", laman sesawang Berita Harian, dicapai pada 18 Oktober 2019, https://www.bharian.com.my/berita/ nasional/2017/07/305557/persijilan-halal-malaysiasukarela-terbuka-semua. 
NH Marmaya, Za Zakaria dan Mohd Nasir Mohd Desa, "Gen Y Consumers' Intention to Purchase Halal Food in Malaysia: A PLS-SEM Approach," Journal of Islamic Marketing 10, no. 3 (2019), 1003-1014.

Noor Afazainiza Afendi, Farah Lina Azizan dan Afiah Isa Darami, "Determinants of Halal Purchase Intention: Case in Perlis," International Journal of Business and Social Research (IJBSR) 4, no. 5 (2014), 118-123.

Noor Raudhiah Abu Bakar, Farah Mohd Shahwahid dan Siti Hawa Radin Ekhsan, "Theory of Planned Behaviour and Halal Compliance," International Journal of Academic Research in Business and Social Sciences 8, no. 5 (2018), 816-829.

Nor Aini Idris dan Mohd Ali Mohd Noor, "Analisis Keprihatinan Pengguna Muslim terhadap Isu Halal-Haram Produk melalui Pembentukan Indeks" (artikel, Persidangan Kebangsaan Ekonomi Malaysia ke VIII, Johor Bahru, 7-9 Jun 2013).

Nor Ardyanti Ahmad, Tunku Nashril Tunku Abaidah dan Mohd Helmi Abu Yahya, "A Study on Halal Food Awareness Among Muslim Customers in Klang Valley" (makalah, International Conference on Business and Economic Research in Klang Valley, 4-5 Mac 2013).

Nor Balkish Zakaria et al., "The Effect on Consumers' Interest. Information Access and Spending Willingness on Halal Products Trustworthiness," Asia-Pacific Management Accounting Journal 12, no. 2 (2017), 184-200.

Nora Mahpar, Mohd Nasaruddin Parzi dan Nur Fatin Mohd Satar, "Restoran pamer tanda 'tiada babi' cetus persoalan, laman sesawang Berita Harian Online, dicapai pada 29 Ogos 2019, https://www.bharian.com.my/node/123917.

Norazah Mohd Suki dan Abang Sulaiman Abang Salleh, "Mediating Effect of Halal Image on Muslim Consumers's Intention to Patronize Retail Stores," Journal Islamic Marketing 9, no. 2 (2018), 338-356.

Norazamimah Bogal, "Religiosity and Halal Food: Attitude of Urban Malay Muslim Consumers" (tesis sarjana, Universiti Malaya, Kuala Lumpur, 2007). 
Noraziah Ali dan Mohd Azlan Abdullah, "The Food Consumption and Eating Behaviour of Malaysian Urbanities: Issues and Concerns," Malaysia Journal of Society and Space 8, no. 6 (2012), 157-165.

Nordin Ahmad, "Persepsi Persatuan Pengguna di Malaysia terhadap Status Pengesahan Halal Jabatan Kemajuan Islam Malaysia (JAKIM)" (tesis kedoktoran, Jabatan Fiqh dan Usul, Akademi Pengajian Islam, Universiti Malaya, 2007).

Norrina Din et al., "Gauging Students' Perception and Attitudes towards Halal Products and Logos," dalam Heritage, Culture and Society, ed. Radzi et al. (London: Taylor \& Francis Group, 2016).

Nur Aniza Quantanih, Noreina dan Nurul Syakinah, "Selecting Halal Food: A Comparative Study of The Muslim and non-Muslim Malaysian Student Consumer" (artikel, International Conforence on Technology Management, Bussiness and Entreprenuship, Melaka, 5 Disember 2013).

Nurul Nabihah Buang et al., "Muslim Consumers' Patronage Intention towards Korean Restaurant Chains in Malaysia" (artikel, The 6th International Conference on Manufacturing, Optimization, Industrial and Material Engineering, 2018).

Nurul Syuhada Mohd Yunus et al., "Predicting Muslim Consumers' Purchase Intention of Previously Retracted and Recertified Halal Products," Journal of Emerging Economies \& Islamic Research 7, no. 1 (2019), 55-64.

Park Thaichon, Sara Quach dan Jiraporn Surachartkumtonkun, "Intention to Purchase at a Fast Food Store: Excitement, Performance and Threshold Attributes," Asian Journal of Business Research 9, no. 1 (2019), 81-101.

Rajeev Batra dan Olli T. Ahtola, "Measuring the Hedonic and Utilitarian Sources of Consumer Attitudes," Marketing Letters 2, no.2 (1990), 159-170.

Redzuan Muhamad, "Pengaruh Budaya Setempat dan Pengetahuan Agama terhadap Pemilihan Makanan Halal dalam Kalangan Pelajar Sekolah Menengah Harian di Lahad Datu, Sabah" (tesis sarjana, Akademi Pengajian Islam, Universiti Malaya, 2017). 
Reham I. Elseidi, "Determinats of Halal Purchasing Intentions: Evidences from UK," Journal of Islamic Marketing 9, no. 1 (2018), 167-190.

Rika Terano dan Zainalabidin Mohamed, "Malaysian Muslim Consumers' Confidence in Purchasing Japanese Food Products in Selangor," Japanese Journal of Agricultural Economics 19 (2017) 43-47.

Sarimah Ismail, "Customer Satisfaction in Malaysian Malay Restaurants Dining Experience" (tesis kedoktoran, University Bournemouth, England, 2012).

Al-Shairazi, al-Muhazzab fi Fiqh al-Imam al-Syafi'i (t.tp.: t.p., 1959) 1:253-258.

Shin-Yi Chou, Inas Rashad dan Michael Grossm, "Fast-Food Restaurant Advertising on Television and Its Influence on Childhood Obesity," The Journal of Law and Economics 5, no. 4 (2008), 599-618.

Siti Fatimah Hamidon dan Hidayat Buang, "Pandangan Pengguna Muslim Terhadap Pemakaian Logo Halal Jabatan Kemajuan Islam Malaysia (JAKIM): Satu Sorotan Literatur," Journal of Shariah Law Research 1, no. 1 (2016), 105-118.

SooCheong (Shawn) Jang, Aejin Ha dan Carol A. Silkes "Perceived Attributes of Asian Foods: From the Perspective of the American customers," International Journal of Hospitality Management 28, no. 1 (2009), 63-70.

Syed Shah Alam dan Nazura Sayuti, "Applying the Theory of Planned Behavior (TPB) in halal Food Purchasing," International Journal of Commerce and Management 21, no. 1 (2011), 8-20.

Sylwia Zakowska-Biemans, "Polish Consumer Food Choices and Beliefs about Organic Food," British Food Journal 113, no.1 (2011), 122-137.

Tuan Sidek Tuan Muda dan Ridzwan Ahmad, "Halal Haram Makanan menurut Imam Syafi'i: Analisis dari Perspektif Maqasid Al-Shari'ah" (Kertas prosiding, 1st International Conference on Islam and Contemporary Issues in The Islamic World: Challenges and Way Forward (ICIC-2016), Universiti Malaya, 5-6 Disember 2016). 
Valarie A. Zeithaml, Leonard L. Berry dan A. Parasuraman, "The Behavioral Consequences of Service Quality," Journal of Marketing 60 (1996), 31-46.

Wahbah Zuhayli, al-Fiqh al-Islami wa Adillatuh, ed. ke-3 (Dimashq: Dar al-Fikr, 1989).

Wim Verbeke dan Gisela Poquiviqui López, "Ethnic Food Attitudes and Behaviour among Belgians and Hispanics Living in Belgium," British Food Journal 107, no. 11 (2005), 823-840.

Yusuf al-Qaradawi, al-Halal wa al-Haram fi al-Islam (Bayrut: alMaktab al-Islami, 1985).

Zaimah Ramli et al., "Malaysia sebagai Pusat Halal Global: Satu Penemuan Awal mengenai Persepsi Halal dalam Kalangan Pengguna di Malaysia," Malaysian Journal of Society and Space 10, no. 6 (2014) 48-56.

Zamra Deraman, Nur Athirah Mohd Borkhan dan Yasinah Abdul Rahman, "Determinat Factors of Consumers' Intention to Eat at Halal Certified Restaurant" (makalah, Proceedings of 124th The IIER International Conference, Tokyo, Japan, 29-30 September 2017).

Zul Ariff Abdul Latiff et al., "Application of Onlie Halal Label among Consumer Intention toward the Halal Label System in Malaysia," Borneo Jurnal of Sciences and Technology 1, no. 1 (2019), 15-20.

Zuliantie Dzul, "Korean Wave's Here to Stay", laman sesawang New Straits Times, dicapai 9 Jun 2020, https://www.nst. com.my/news/2016/11/192393/korean-waves-here-stay.

Zuraini, Muhammad Afiq dan Nurzulain, "The Influence of CrossGeneration Attitude on Halal food Products," Malays Appl. Biol. 48, no. 2 (2019), 41-46. 